\title{
On the Role of Phonological Processing in L2 Reading
}

\author{
Mohammad Khatib \\ Allameh Tabataba'i University, Tehran, Iran \\ Email: mkhatib27@yahoo.com \\ Jalil Fat'hi \\ Allameh Tabataba'i University, Tehran, Iran \\ Email: jfathi13@yahoo.com
}

\begin{abstract}
This paper provides a review of ideas and research regarding the role of phonological processing as a bottom-up, component processing mechanism in second language reading comprehension. Firstly, it sketches a brief history of approaches and theoretical models towards $L 2$ reading comprehension in the SLA literature. Secondly, it acknowledges the fact that with the undue dominance of top-down psycholinguistic models, the role of bottom-up processes in L2 reading has been systematically neglected. And finally an accumulated body of literature is presented which comprehensively delineates the studies carried out to examine the contributory role of phonological processing as a type of bottom-up proceesing in $\mathrm{L} 2$ reading.
\end{abstract}

Index Terms - phonological processing, top-down psycholinguistic models, bottom-up processing

\section{INTRODUCTION}

Most scholars would agree that reading is one of the most important skills for educational and professional success (Alderson, 1984). In highlighting the importance of reading comprehension Rivers ( 1981; p. 147) stated that "reading is the most important activity in any language class, not only as a source of information and a pleasurable activity, but also as a means of consolidating and extending one' s which are knowledge of the language".

Reading reinforces the learner's other language skills. Krashen (1981) confirms that those who read more, have larger vocabularies, do better on test of grammar and write better (Kim \& krashen, 1997). Chastian (1988, p. 218) while accepting the significance of reading for meaning claimed that all reading activities serve to facilitate communication fluency in each of the other language skills.

According to Eskey (1988), in advanced levels of second language the ability to read the written language at a reasonable rate and with good comprehension has long been recognized to be as oral skills if not more important.

Reading comprehension, like any other language ability, is an abstract concept, and there are many arguments on its nature. For many years, language skills were classified as active and passive skills. Active skills included speaking and writing, because they provided overt evidence of language production. On the other hand, listening and reading considered as passive skills, because they did not display any apparent manifestation of language element - production. Rivers (1981; p. 67) states that:

reading is sometimes referred to as a passive or receptive skill, but if we examine the abilities that come into play influence direct reading with comprehension of meaning it is clear that readers are far from passive during this activity.

\section{AN OVERVIEW OF APPROACHES}

Contemporary to the emergence of cognitive code learning theory, scholars began to study the nature of reading as a mentalistic process. In this view, two main movements developed: the first claimed that reading comprehension can be divided into many sub skills, and the second maintained that reading comprehension is a general integrative ability.

Early investigation of second language reading assumed reading comprehension processes as a rather passive, bottom-up mechanism. From the adopted perspective of those days, reading comprehension process was viewed primarily as a decoding process of reconstructing the author's intended meaning via recognizing the printed letters and words, and building up a meaning for a text from the smallest textual units at the bottom (letters and words) to larger units at the top (phrases, clauses, links). As a result, the problems of second language reading and reading comprehension were viewed as being essentially decoding problems, deriving meaning from print. Eskey (1988) mentioned the need for reading teachers to 'hold in the bottom' on the grounds that 'top-down' orientation leads to neglect of the language data that reader is necessarily drawing upon. Within this orientation, some scholars proposed activities which encouraged automated processing of words by asking students to discriminate rapidly between graphonically similar words. Some other scholars highlighted the syntactic awareness of word and sentence structures. 
This model starts with the printed stimuli and works its way up to the higher level stages. The sequence of processing proceeds from the incoming data to higher level encodings.

This model, basically, postulated the teaching of reading to be started with smallest linguistic units, single letters, mixture of letters, words and up to phrases and sentences, etc. The text- based view of reading implies that the proper approach in teaching students to read is to teach the language forms they need to know to be able to comprehend the reading (Chastain , 1988).

On the other hand, these models have not been away from criticism because of the heavy burden this process would make on the short-term memory. For example, there are more than 166 letter-to -sound correspondences in English, thus reading would be a slow and arduous process (Davies, 1995). In addition, this model does not account to make sense of the text (Barnett, 1989).

In the early seventies, Goodman's psycholinguistic model of reading (later named the top-down or concept-driven model) began to have an impact on views of second language reading. This approach was concerned with the strategies or resources which readers employ in reading and learning to read. Those favoring this approach conceptualize reading as a language activity as well as a psychological process. This model argued that reading is best seen not as the matching up of visual symbol to sound realization in a linear manner, but as a process heavily mediated by the reader's ability to make informed predictions as one goes through the text.

Quite contrary to text-based view of reading comprehension, stands the inside-the-head or top-down processing view of reading. Top -down model of reading postulates a non-linear view of the process in which comprehension begins with the reader's contribution, i. e. from higher levels of processing, and proceeds to use the lower levels selectively.

Thus, a top -down approach to reading is the "making of predictions about the text based on prior experience or background knowledge, and then checking the text for confirmation or refutation of those predictions ( Carrell , 1988, p.101). This approach is thus conceptually driven (Carrell, 1991).

Carrell (1991) states that readers contribute more information to interpreting a text than the print on the page. This holds that any written or spoken text does not carry meaning, but rather only provides directions for listeners or construct meaning from their own, previously acquired knowledge.

Thus, according to Goodman (1967, p.131), making sense of a text is a four - step process (reported in Barnett, 1989):

1. Predicting: readers predict the grammatical structures based on their knowledge of the language and semantic concepts to obtain its meaning .

2. Sampling: readers sample the text to confirm their predictions (this is indirect contrast to bottom-up reading because they do not need to see every word or letter ).

3. Confirming: the readers confirm their guesses.

4. Correcting: the readers revise their predictions if necessary.

Additionally, Smith (1982) adds that readers use non - visual information (prior knowledge of the subject) in making and confirming predictions. Dubin and Bycina (1991) hold that, according to this newer model, the role of readers was considered to be quite active: They predict meaning as they read; they take in large chunks of text at a time. They do not attend to separate letters, rather they match what they already know with the meaning they derive from the text (cited in Celce-Murcia 2001).

However, this model has been criticized because it fails to account for the reader who can be frustrated by a text with a large amount of unfamiliar vocabulary (Barnett, 1989) or readers who are able to understand a text for which they have little background knowledge (Stanovich , 1980).

The top-down processing perspective into second language reading had a an extremely profound impact upon the second language reading research, to an extent that it was viewed as a substitute for the bottom-up perspective, rather than its complement.

However, recent research indicates the potential for some rapprochement between opposing camps, particularly those who emphasize both reading as product and reading as process. As schema theory research has attempted to make clear, efficient and effective reading (in L1 and L2) requires both top-down and bottom-up strategies operating interactively model (Koda, 2005). Both top-down and bottom-up processes, functioning interactively, are necessary to an adequate understanding of second language reading and reading comprehension. (Carrell, 1988, pp. 1-4)

In spite of the emergence of the interactive model, most of the research in L2 and foreign language reading, still influenced by the dominance of the top-down psycholinguistic views of L1 reading, used to focus on the role of higher level knowledge sources such as background knowledge and the knowledge of syntactic and semantic structures in processing text (e.g., Barnett, 1989; Carrell, 1988; Cziko, 1978, 1980; Floyd \& Carrell, 1987).This psycholinguistic framework, viewing reading as a game of guessing, sampling, predicting, and verifying top-down hypotheses, emphasizes the role of higher level syntactic and semantic processes and minimizes the role of component and bottomup processes.

While the literature in $\mathrm{L} 2$ reading research is still overwhelmingly dominated by top-down psycholinguistic frameworks (Koda, 2005), the pendulum has swung back towards a more balanced view regarding the role of different component processes in $\mathrm{L} 1$ reading.

In line with this shift of attention and orientation in L1 reading research, in the last two decades, the attention of the SLA researchers has shifted from top-down views of reading process towards bottom-up view of investigating reading 
comprehension mechanism. In recent years, there has been a great deal of work devoted to the study of component skills that are necessary to sustain a success in second language reading (e.g. Koda, 2005; Leong, Hau, Cheng, and Tan, 2005; Nassaji \& Geva, 1999; Nation \& Snowling, 2004; Segalowitz, Poulsen, \& Komoda, 1991; Stanovich, 1986; Stanovich \& West,1989). From this perspective, it is claimed that information processing of text is driven by both bottom up and top-down information. Prior knowledge with the help of accelerated bottom-up processes influences the perception, speed, and conceptual framework in reading processes. This view proposes multiple, independent, parallel routes simultaneously processing information with a cross-checking mechanism. Active routes are contingent upon the information presented, the individual's knowledge and the task demands (Grabe, 2004). In this regard, an increasing amount of interest has been focused on the relationship between phonological awareness which is a basic, lower-level component processing and reading development (e.g. Bialystok, Majumder, \& Martin, 2003; Blaiklock, 2004; Deacon \& Kirby, 2004; Engan, 2002; Lafrance \& Gottardo,2005; Nassaji \& Geva, 1999).

Phonological Processing as a Bottom-up Processing Mechanism in Reading

Reading, as one of the most attention-grabbing language skills, is a complex cognitive skill which uses various interactive processes. One of alluring issues in this skill is relationship between phonological component and semantic representation. From this perspective, it is known that information of several sorts (phonetic, lexical, syntactic, and pragmatic) is processed during the comprehension process as the meaning is constructed (Bialystok, et al. 2003; Blaiklock, 2004; Byrne, 1991; Carroll \& Snowling, 2004; Coltheart et al. 1988; Harris and Coltheart, 1986). That said, comprehension in reading, which is affected by both lower-level components and higher-level components, is a multifaceted set of processes, not an all-or-none operation. The line of evidence in favor of the effect of phonological component comes from several sources.

In this regard, most of the recent body of research hold the view that there is an interaction between the processing of the physical stimuli (bottom-up processing) and the context provided by expectation and previous knowledge (top-down processing) (Carrell et al., 1998). In line with this perspective, Koda (1992, pp. 52-57) indicates that lower level verbal processing skills (e.g., phonological processing) is one of the four major reader-related skills. He further adds that little attention has been paid to the relationship between lower level verbal processing skills and reading comprehension, but a number of theorists in cognitive psychology claim that deficiency in lower level processing operations strains the limited capacity of short-term memory and inhibits text integration into a meaningful sequence (e.g., Leong et al. 2005; Lesaux \& Siegel, 2003; Nation \& Snowling, 2004). Based on his findings, he holds that efficient lower level verbal processing operations are essential for successful performance in FL reading comprehension tasks.

More specifically, one of the lower level verbal processing mechanisms is phonological processing which is the task of linking printed letters to phonemes. This reading-specific processing is especially difficult for FL readers because of the lack of one-to-one correspondence between phonemes and graphemes.

In one study done by Deacon and Kirby (2004), the roles of morphological and phonological awareness on the reading development were taken into account. It was a longitudinal study which took 4 years. They compared two factors, namely phonological and morphological awareness, in three aspects of reading development: pseudoword reading, reading comprehension, and single word reading. The results of their study divulged that morphological awareness contributed significantly to pseudoword reading and reading comprehension, after controlling prior measures of reading ability, verbal and nonverbal intelligence, and phonological awareness. This contribution was comparable to that of phonological awareness and remained 3 years after morphological awareness was assessed. In contrast, morphological awareness rarely contributed significantly to single word reading. They argued that these results provided evidence that morphological awareness had a wide-ranging role in reading development, one that extended beyond phonological awareness.

Another study done by Nassaji and Geva(1999) investigated the role of phonological and orthographic processing skills in adult second language reading. The subjects were 60 ESL graduate students; all were native speakers of Farsi. Three types of ESL reading measures were used as criterion variables: reading comprehension, silent reading rate, and the ability to recognize individual words. Data were analyzed using correlational and hierarchical multiple regression. The analysis of the collected data revealed that efficiency in phonological and orthographic processing contributed significantly to individual differences on the reading measures. In particular, efficiency in orthographic processing contributed to the reading measures independently of syntactic and semantic measures. The study suggested that it was useful to consider individual differences in ESL reading with respect to individual differences in lower level processes particularly the efficiency with which readers process phonological and orthographic information.

This research (Nassaji and Geva,1999) indicated that information about individual differences in the efficiency with which L2 readers process phonological and orthographic information helps us to understand individual differences in ESL reading. It suggested that the role of lower level graphophonic processing should not be overlooked in L2 reading, even when readers are proficient adult L2 readers.

Droop and Verhoeven (2003) gave much importance to the role of oral language proficiency in reading comprehension because the L2 reading comprehension skills are more dependent upon lexical knowledge than the L2 decoding skills. Bilingual Turkish-Dutch children, although comparable in word recognition, performed more poorly in reading comprehension than their monolingual Dutch-speaking peers. The authors attributed this lower level of comprehension to the lower performance in syntactic ability and oral fluency. Measures of Dutch oral language 
proficency included both expressive and receptive vocabulary tasks, and an expressive syntactic task. However, both for native speakers and for L2 speakers, decoding skills played only a minor role in the development of reading comprehension, and according to the authors, decoding and reading comprehension appear to develop as independent skills from third grade on (Droop \& Verhoeven, 2003).

In agreement with these findings, studies have demonstrated a significant effect of oral language proficiency in L2 reading comprehension, although measures of L2 decoding predicting L2 reading comprehension were not analyzed. Geva and Ryan (1993) conducted a cross-sectional study with 73 students in Grades 5 to 7, who were learning to read in English (L1) and Hebrew (L2) concurrently. Regression analysis showed that Hebrew oral proficiency, as measured by teachers' global ratings, accounted for $29.8 \%$ of the variance on Hebrew reading comprehension scores.

However, Lesaux and Siegel (2003) reported different results. A study with ESL second graders of diverse linguistic background found that oral comprehension and naming were not significant predictors of reading comprehension performance, whereas rhyme detection explained $17 \%$ of the variance, and letter identification explained $7 \%$ of the variance. ESL children performed at levels comparable to those in their L1.

Similarly to studies in the L1, oral language proficiency seems to account for greater variance in reading comprehension once students become proficient in decoding skills. Proctor, Carlo, August, and Snow (2005) analyzed the role of English vocabulary, listening comprehension, and word reading fluency in L2 English reading comprehension among fourth-year intermediate-level Spanish-speaking ELLs. The authors observed that whereas vocabulary, listening, and L2 alphabetic knowledge exerted a role in reading comprehension, speed of decoding did not contribute to significant variance in the model.

Torgesen (2000), having devoted some investigation, summarized the importance of phonological awareness in acquiring accurate word reading skills. According to Torgesen (2000): First, phonological awareness helps children understand the alphabetic principle. Second, it helps children realize the regular ways that letters represent sounds in words. Lastly, it makes it possible to generate possibilities for words in context that are only partially sounded out.

Moreover, as Koda (2005) states, poor readers uniformly are handicapped in a wide variety of phonological tasks. Furthermore, Metsala \& Ehri (1998) state that comprehension is a meaning-construction process, which involves integral interaction between text and reader. Extracting phonological information from individual words constitutes one of the first and most important steps in this endeavor. Also phonological skills have a direct, and seemingly causal relationship with reading ability knowledge of letter patterns and their linkages to sounds facilitates rapid automatic word recognition; such knowledge evolves gradually through cumulative print-processing experience; and limited word-recognition skills tend to induce over reliance in context (p.254).

The central tenet of the mentioned studies is that links between phonological form and meaning can then produce meaning activation that is indirectly 'mediated' through phonology. One such model is the Interactive Constituency Theory (ICT) (Perfetti \& Tan, 1998; 1999 cited in Perfetti et al.2003). The ICT assumes that a phonological form is routinely activated as part of word identification because it is a constituent of the identified word. This phonological activation rapid and may precede the direct activation of specific word meaning in many situations. However, the ICT further assumes that phonological activation is diffuse across characters sharing the same pronunciation.

William and Lovatt (2003) have considered phonological awareness not only as a fundamental factor determining learner's reading ability but also as an important element helping vocabulary learning in both normal and languageimpaired adults and children in L2 acquisition.

Snowling et al. (1991) have suggested that phonological awareness training perhaps should be incorporated into classroom activities to help young FL learners enhance word recall and pronunciation-learning ability or to ameliorate word-learning problems in FL.

Segalowitz et al. (1991) have also argued that the modification and specification of the word-referent relationship cannot proceed if the phonological pattern is obscure and incomplete. Thus, even though FL word learning is not a simple phonological issue, the establishment of a complete and solid phonological representation for a word still appears to be the first and the most important springboard to success in early FL vocabulary acquisition for a young FL learner.

Phonological awareness is an important prerequisite for literacy acquisition (Dickinson et al., 2004). They have believed that a basic prerequisite to word decoding is to become aware of phonological structure of words. As William and Lovatt (2003) have argued phonological awareness is a critical precursor, correlate, and predictor of reading achievement. Experimental evidence of the importance of phonological awareness interventions comes from phonological awareness studies of 5-to-6-year-old children that boosted later reading achievement. (ibid).

Evidence has been put forth demonstrating phonological recoding during silent reading from an array of research paradigms (e.g., Read, 1983). Observational work on early reading behavior with children suggests that children sound out the visual information and in a sense listen to themselves (e.g., McCusker, Hillinger, \& Bias, 1981).

Rubenstein, Lewis, and Rubenstein (1971) claimed phonological representations are used to search for lexical entries. They were the first to use a lexical decision task in their methodology. They examined factors consisting of orthography and phonology by manipulating the use of words, nonwords, pseudowords, homophones, and pseudohomophones. As a result of their findings they argued that a phonological representation must be used on visually presented words in order to search the lexicon. 
Van Orden's (1987) findings support Rubenstein et al's (1971) claim. Van Orden (1987) argued for a phonological mediation hypothesis - meaning is accessed through sound from print. That is, as one reads the printed text the print is converted to sound prior to meaning or as a means to meaning.

Van Orden has conducted a series of experiments demonstrating the important role of phonological mediation in various tasks involving print to meaning. He argued that computed phonological codes are a potent force in word identification (Van Orden, Johnston, \& Hale, 1988).

In an attempt to identify the component processes of reading that discriminate between skilled and less-skilled individuals, most of the research indicates that readers differ in their perception of spatial location information (Mason, 1980); in the speed with which they access memory codes for visually presented patterns (e.g. letters) (Jackson and McClelland, 1979; Jackson, 1980); in the efficiency of their phonological-coding processes (Perfetti and Lesgold, 1977)

In addition to the above-mentioned evidences in favor of the effect of phonological component on comprehension, other researchers suggest that different lower-level processing operations-sound discrimination and word recognitionare essential for successful performance in reading. on the basis of their research, it is also enunciated that the poor readers' problems in language comprehension result from insufficiencies of verbal working memory that are associated with general difficulties in phonological processing (Wagner and Torgesen, 1987; Cupples and Holmes, 1992; Koda, 1992; Carlisle and Nomanbhoy, 1993).

Reading, as an instance of language understanding system is basically concerned with the process by which words are recognized. Theorists have offered different speculations regarding the stated issue, in which the relationship between visual route, sound route, and semantic entry has differently been described (Perfetti et al., 2003; Van Ordern, 1987).

In connection with the theories of word recognition, Garnham (1985, pp. 57-62) introduces the Phonological Recoding Hypothesis (PRH) as a solution to understanding words in the process of reading. Following the framework of the Indirect-Access Hypothesis, he suggests, "what is learned is a set of rules called Grapheme-Phoneme Correspondence (GPC) rules that translate letter patterns into sound patterns."

Garnham (1985) further explains that perhaps all comprehension depends on such translation, and the mental lexicon can only be accessed via sound patterns. In other words, according to PRH, letters recode into sounds and it is merely the sound of word which activates the mental lexicon and causes the access of relevant information from the mental lexicon.

Leong et al. (2005) pointed out that children's phonological sensitivity to the speech sound structure of spoken words was important in learning to read for alphabetic language system, for example, English (Adams, 1990; Byrne, 1991; Wagner \& Torgesen, 1987). Phonological memory and phonological access to lexical items have been shown to be the predictor of reading acquisition (Wagner \& Torgesen, 1987).

\section{CONCLUSION}

Given the abundance of studies (most of which presented in this paper) confirming the contributory role of phonological processing in reading comprehension, the importance of both the text and the reader in the reading process should be recognized, an amalgamation of the two leads the SL theorists to the interactive approach. Reading here is the process of combining textual information with the information the reader brings to a text. The interactive model (Stanovich 1980) stresses both what is on the written page and what a reader brings to it using both top-down and bottom-up skills. It views reading is the interaction between reader and text. The overreliance on either mode of processing to the neglect of the other mode has been found to cause reading difficulties for SL learners (Carrell 1988, p. 239).

To sum it up, good readers are both good decoders and good interpreters of text, their decoding skills becoming more automatic but no less important as their reading skill develops (Eskey 1988). To properly achieve fluency and accuracy, second language readers must work at perfecting both their bottom-up recognition skills and their top-down interpretation strategies. Good reading (that is fluent and accurate reading) can result only from a constant interaction between these processes.

\section{REFERENCES}

[1] Adams, M. J. (1990). Beginning to read [electronic resource]: thinking and learning about print (pp.299-320). Cambridge Mass.: MIT Press.

[2] Alderson, C. (1984). Reading in a foreign language: a reading problem or a language problem. In Alderson, C\& urquuhart, A. H. (Eds.), Reading in Foreign language (pp.114-141). London: Longman.

[3] Bar-Shalom, E.G., Crain, S., and Shankweiler, D. (1993). "A comparison of comprehension and production abilities of good and poor readers." Applied Psycholinguistics, 14: 127-227.

[4] Barnett, M. A. (1989). More than meets the eye. Foreign language reading. Englewood Cliffs, NJ: Center For Applied Linguistics.

[5] Bialystok, E., Majumder, S., \& Martin, M. M. (2003). Developing phonological awareness: Is there a bilingual advantage? Applied Psycholinguistics, 24(1),27-44. 
[6] Blaiklock, K. E. (2004). The importance of letter knowledge in the relationship between phonological awareness and reading. Journal of Research in Reading,27(1), 36-57.

[7] Byrne, B. (1991). The role of phonological awareness in reading acquisition. Australian Journal of Reading, 14(2), 133-139.

[8] Carlisle, J.F. and Nomanbhoy, D.M. (1993). "Phonological and morphological awareness in first graders." Applied Psycholinguistics, 14: 177-195.

[9] Carrell, P. L. (1988). Schema interference in ESL reading, in Carrell, P. L., Devine, J. and Eskey, D. E. (Eds.), Interactive approaches to second language reading (pp.128-142). Cambridge: Cambridge University Press.

[10] Carrell, P.L. (1991). Second language reading: reading ability or language proficiency? Applied Linguistics 12: 159-179.

[11] Carrell, P., Devine, Y., and Eskey, D. (1988). Interactive Approaches to second language reading. Cambridge: Cambridge University Press.

[12] Carroll, J. M., \& Snowling, M. J. (2004). Language and phonological skills in children at high risk of reading difficulties. The Journal of Child Psychology and Psychiatry and Allied Disciplines, 45(3), 631-640.

[13] Celce-Murcia, M. (2001). Teaching English as a second foreign language (third edition). Heinle \& Heinle.

[14] Chastain, K. (1988). Developing second language skills: Theory and practice ( $3^{\text {rd }}$ ed .). Chicago: HBJ.

[15] Coady, J. (1979). A psycholinguistic model of the ESL reader. In R. Mackay, B. Barkman, \& R. R. Jordan (Eds.), Reading in a second language (pp. 5-12). Rowley, MA: Newbury.

[16] Coltheart, V., Laxon, V., Richard, M., \& Elton, C. (1988). Phonological recoding in reading for meaning by adults and children. Journal of Experimental Psychology: Learning, Memory, and Cognition, 14, 387-397.

[17] Cupples, L. and Holmes, V.M. (1992). "Evidence for a Difference in Syntactic Knowledge between Skilled and Less Skilled Adult Readers." Journal of Psycholinguistic Research, 21: 249-273.

[18] Cziko, G. A. (1978). Differences in first- and second-language reading: The use of syntactic, semantic and discourse constraints. Canadian Modern Language Review, 34, 473-489.

[19] (1980). Language competence and reading strategies: A comparison of first and second language oral reading errors. Language Learning, 30, 101-114.

[20] Davies, F. (1995). Introducing Reading. London: Penguin English.

[21] Deacon, S. H., \& Kirby,J.R. (2004). Morphological awareness: Just "more phonological"? The roles of morphological and phonological awareness in reading development. Applied Psycholinguistics 25 (2004), 223-238.

[22] Dickinson, D. K., McCabe, A., Clark-Chiarelli, N., \& Wolf, A. (2004). Cross-language transfer of phonological awareness in low-income Spanish and English bilingual preschool children. Applied Psycholinguistics: Psychological and Linguistic Studies across Languages and Learners, 25(3), 323-347.

[23] Droop M. and Verhoeven L. (2003). Language proficiency and reading ability in first and second language learners. Reading Research Quarterly, 38, 78-103. Quoted in Grabe William (2004). Research on teaching reading. Annual Review of Applied Linguistics, 24, 44-69.

[24] Dubin, F. \& Bycina, D. (1991). Academic reading and the EFL/ESL teacher. In celce - Murcia, M. Teaching English as a second or foreign language (pp.195-215).New York: Heinle \& Meinle publishers.

[25] Engan, L. (2002), Phonological and Reading Comprehension, Reading and Writing: An Interdisciplinary Journal 15: 613-631.

[26] Eskey, D. (1988). Holding in the bottom: An interactive approach to the problem of sound language readers. In (Carrell, P. L., Devine, J. and Esky, D. E. Eds.), Interactive approaches to second language learning. (pp.130-152). New York: Cambridge University Press.

[27] Floyd, P., \& Carrell, P. L. (1987). Effects on ESL reading of teaching cultural content schemata. Language Learning, 37, 89108.

[28] Garnham, A. (1989). Psychology: Science of Mind and Behavior. London: Hudder and Stoughton.

[29] Geva, E., \& Ryan, E. B. (1993). Linguistic and cognitive correlates of academic skills in first and second languages. Language Learning, 43, 5-42.

[30] Grabe, W. (2004). Research on teaching reading. Annual Review of Applied Linguistics, 24, 44-69.

[31] Harris, M. and Coltheart, M. (1986). Language Processing in Children and Adults: An Introduction. London: Rutledge and Kegan Paul.

[32] Hasher, L. and Zacks, R.T. (1979). "Automatic and Effortful Processes in Memory.” Journal of Experimental Psychology: General, 108:356-388.

[33] Haynes, M., \& Carr, T. (1990). Writing system background and second language reading: A component skills analysis of English reading by native speakers of Chinese. In T. Carr \& B. Levy (Eds.), Reading and its development: Component skills approaches (pp. 375-421). San Diego: Academic.

[34] Jackson, M.D. (1980). "Further Evidence for Relationship between Memory Acess and Reading Ability." Journal of Verbal Learning and Verbal Behavior, 19: 683-694.

[35] Jackson, M.D. and McCelland, J.L. (1979). "Processing Determinants of Reading Speed." Journal of Experimental Psychology: General, 108: 151-181.

[36] Kim, H. \& Krashen, S. (1997). why don't language acquirers take advantage of the power of reading. TESOL Journal, 6, $26-28$.

[37] Koda, K. (2005). Insights into second language reading: a cross-linguistic approach. Cambridge, UK: New York, NY: Cambridge University Press.

[38] Koda, K. (1992). The effect of lower-level processing skills on FL reading performance: Implications for instruction. The Modern Language Journal, 76, 505-512.

[39] Krashen, S. (1981). Second language acquisition and second language learning. New York: Pergamon Press.

[40] Lafrance, A., \& Gottardo, A. (2005). A longitudinal study of phonological processing skills and reading in bilingual children. Applied Psycholinguistics, 26(4), 559-578.

[41] Leong, C.K.; Hau, K.T.; Cheng, P.W., and Tan, L.H. (2005), Exploring two-wave Reciprocal Structural Relations among Orthographic Knowledge, Phonological Sensitivity, Reading and Spelling English Words by Chinese Students, Journal of Educational Psychology, Vol. 97, pp. 591-600. 
[42] Lesaux, N.K. and Siegel, L.S. (2003). The Development of Reading in Children Who Speak English as a Second Language. Developmental Psychology, 39, 6, 1005-1019.

[43] Mason, M. (1980). "Reading Ability and Encoding of Item and Location Information." Journal of Experimental Psychology: Human Perception and Performance, 6: 89-98.

[44] McCusker, L. X., Hillinger, M. L., \& Bias, R. G. (1981). Phonological recoding and reading. Psychological Bulletin, 74(5), 309-326.

[45] McLaughlin, B. (1987). Theories of second language learning. New York: Edward Arnold.

[46] McLeod, B., \& McLaughlin, B. (1986). Restructuring or automatization? Reading in a second language. Language Learning, 36, 109-127.

[47] Metsala, J. L. \& Ehri, L. C. (1998). Word recognition in beginning literacy (pp.3-40) [electronic resource]. Mahwah, N.J.: L. Erlbaum Associates.

[48] Nassaji, H., \& Geva, E. (1999). The contribution of phonological and orthographic processing skills to adult ESL reading: Evidence from native speakers of Farsi. Applied Psycholinguistics, 20, 241-267.

[49] Nation, K., \& Snowling, M. J. (2004). Beyond phonological skills: Broader language skills contribute to the development of reading. Journal of Research in Reading, 27(4), 342-356.

[50] Proctor, C. P., Carlo, M. S., August, D., \& Snow, C. E. (2005). Native Spanish-Speaking Children Reading in English: Toward a model of comprehension. Journal of Educational Psychology, 97, 246-56.

[51] Perfetti, C. A., \& Lesgold, A. M. (1977). Discourse comprehension and sources of individual differences. In M. A. Just \& P. A. Carpenter (Eds.), Cognitive processes in comprehension. Hillsdale, NJ: Erlbaum.

[52] Perfetti, C.A., Bell, L.C., and Delaney, S.M. (1988). "Automatic (Pre-lexical) Phonetic Activation in Silent Word Reading: Evidence from Backward Masking.” Journal of Memory and Language, 27: 59-70.

[53] Perfetti, C. A., Koda K.\& Wang M. (2003). Alphabetic and nonalphabetic L1 effects in English word identification: a comparison of Korean and Chinese English L2 learners. Cognition, 87(2), 129-149.

[54] Read, J. D. (1983). Detection of Fs in a single statement: The role of phonetic recoding. Memory \& Cognition, 11 (4), $390-399$.

[55] Rivers, W. M. (1981). Teaching foreign language skills. (2 ${ }^{\text {nd }}$ ed.). London: The University of Chicago Press.

[56] Rubenstein, H., Lewis, s. S., \& Rubenstein, M. A. (1971). Evidence for phonemic receding in visual word recognition. Journal of verbal Learning \& verbal Behavior, 10 (6), 645-657.

[57] Segalowitz, N. (2003). Automaticity and second languages. In C. Doughty and M. H. Long (Eds.), The Handbook of Second Language Acquisition (pp. 382-408).

[58] Segalowitz, N., Poulsen, C., \& Komoda, M. (1991). Lower-level components of reading skill in higher level bilinguals: Implications for reading instruction. AILA Review, 8, 15-3. Malden, MA: Blackwell.

[59] Shiffrin, R.M. and Schneider, W. (1977). "Controlled and Automatic Human Information Processing. II: Perceptual Learning, Automatic, Attending and a General Theory." Psychological Review, 84: 127-190.

[60] Smith, F. (1982). Understanding Reading. 3 rd Ed. New York: Holt, Rinehart, and Winston.

[61] Snowling, M., Chiat, S., \& Hulme, C. (1991). Words, nonwords, and phonological processes: Some comments on Gathercole, Willi, Emslie and Baddeley. Applied Psycholingustics. 12, 369-73.

[62] Stanovich, K. E. (1980). Attentional and automatic context effects in reading. In A. M. lesgold \& C. A. perfetti (Eds.), Interactive Processes In Reading (pp.241-267). Hillsdale, NJ: Lawrence Erlbaum.

[63] Stanovich, K. E. (1986). Matthew effects in reading: Some consequences of individual differences in the acquisition of literacy. Reading Research Quarterly, 21, 360-(1984). The interactive-compensatory model of reading: A confluence of developmental, experimental, and educational psychology. RASE, 5, 11-19.

[64] Stanovich, K. E., \& West, R. F. (1989). Exposure to print and orthographic processing. Reading Research Quarterly, 24, 402433.

[65] Torgesen, J. K. (2000). A basic guide to understanding, assessing, and teaching phonological awareness. Austin, Tex.: Pro-Ed Mass.

[66] Torgesen, J. K., Wagner, R. K., Rashotte, C. A., Burgess, S., \& Hecht, S. (1997). Contributions of phonological awareness and rapid automatic naming ability to the growth of word-reading skills in second- to fifth-grade children. Scientific Studies of Reading, 1(2), 161-185.

[67] Van Orden, G.C. (1987). “A Rows Is a Rose: Spelling, Sound, and Reading.” Memory and Cognition, 15: 181-198.

[68] Van Orden, G. e., Johnston, J. e., Hale, B. L. (1988). Word identification in reading proceeds from spelling to sound to meaning. Journal of Experimental Psychology; Learning. Memory. \& Cognition, 14 (3), 371-386.

[69] Wagner, R.K. and Torgesen, J. K. (1987). "The Nature of Phonological Processing and Its Role in the Acquisition of Reading Skills.” Psychological Bulletin, 101: 192-212.

[70] William, J.N, \& Lovatt, P. (2003). Phonological memory and rule learning. Language Learning Journal. 53, (1), 67-121.

Mohammad Khatib is Assistant Professor of TEFL at Allameh Tabataba'i University in Iran. He holds a Ph.D. in TEFL (Allameh Tabataba'i University, 1999), an M.A. and a B.A. in English Literature from Tehran University (1977 and 1972 respectively).

He began teaching at Allameh in 1981 and presently offers graduate and post-graduate courses in SLA Theories, Methodology, Literature in EFL Classes and English Literature. His main areas of interest include SLA Theories, language learning strategies, culture and the integration of language and literature. He has published some articles on TEFL in Iranian Journals of Applied Linguistics. He has translated a book of short stories from famous writers of the world and published a guidebook on Shakespeare's selected sonnets. 
Jalil Fat'hi is currently a Ph.D. candidate in TEFL at Allame Tabatabaii University. He is a visiting lecturer at Allameh Tabataba'i University. He has presented several papers at Applied linguistics conferences held in Iran. His research interests are Language Testing, Universal Grammar Accessibility in SLA, Teacher Education. 